Public Health of Indonesia

Yunancy, S., Nurlaela, E., \& Rusli, R. (2020). Public Health of Indonesia: 6(4), 145-156

http://stikbar.org/ycabpublisher/index.php/PHI/index

Original Research

\title{
HAZARD ANALYSIS CRITICAL CONTROL POINT (HACCP) ON PALUMARA FISH SOUP IN THE NUTRITION INSTALLATION OF THE REGIONAL GENERAL HOSPITAL, INDONESIA
}

\author{
Sri Yunancy*, Euis Nurlaela, Rahmatunna Rusli \\ Department of Nutrition Study Program, Poltekkes Kemenkes Kendari, Southeast Sulawesi, Indonesia
}

Received: 2 November 2020 | Accepted: 11 November 2020

DOI: https://dx.doi.org/10.36685/phi.v6i4.358

Correspondence:

Sri Yunancy

Department of Nutrition Study Program, Poltekkes Kemenkes Kendari

Southeast Sulawesi, Indonesia

Mobile: 085399442905

Email: $\underline{\text { rriyunancy20@gmail.com }}$

Copyright: (C) 2020 the author(s). This is an open-access article distributed under the terms of the Creative Commons Attribution Non-Commercial License, which permits unrestricted non-commercial use, distribution, and reproduction in any medium, provided the original work is properly cited.

\begin{abstract}
Background: One of the government efforts in Indonesia to protect consumers and producers of healthy and safe food is to enforce the Republic of Indonesia's Law No. 23 of 1992 concerning Health (Part Four: Safety of Food and Beverages). Therefore, designing the HACCP design at the hospital is necessary to ensure food safety.

Objective: This study aimed to find out how the design is appropriate for the food safety system with the HACCP Principles Approach in the Palumara Fish Soup Processing in the Nutrition Installation of the Kendari City Regional General Hospital, Indonesia.

Methods: This study was descriptive with a qualitative approach conducted on 15-17 July 2019 with Palumara fish soup samples observed three times in the third menu cycle.

Result: The critical points in the processing of Palumara fish soup include improper foodstuffs, washing of impurities in the tools and foodstuffs, boiling and stirring (the level of food maturity), stripping (i.e., the inedible part), and contamination from workers and containers.

Conclusion: The nutrition installation at the Kendari City Regional General Hospital has not implemented Good Manufacturing Practices (GMP) as a whole, both from manpower, buildings, sanitation facilities and equipment. In addition, the hospital has not implemented HACCP in the food processing process, from the reception to distribution stage, so there are risks and dangers in Palumara fish soup.
\end{abstract}

Keywords: HACCP, Palumara fish soup, general hospital

\section{BACKGROUND}

One of the government efforts in Indonesia to protect consumers and producers of healthy and safe food is to enforce the Republic of Indonesia's Law No. 23 of 1992 concerning health (part four: safety of food and beverages), Law of the Republic of Indonesia No. 7 of 1996 concerning food, Government Regulation No. 69 of 1999 concerning food labels and ads, Government Regulation No. 28 of 2004 concerning Food Safety, Quality and Nutrition. The Indonesian government also has Law no. 8 of 1999 concerning protection.

The hospital is one of the institutions that conducts food and beverage activities on a regular basis, so that in its implementation, food and beverage administration in a hospital requires special handling. Patients who are being treated in hospital are regular consumers of food and beverage activities in a hospital. The 
patient's body is in a weak condition so that it is very susceptible to various diseases including diseases that are transmitted through food. Therefore, food management in hospitals needs more careful attention (Departemen Kesehatan Republik Indonesia, 2006). There are several cases of disease and food poisoning as well as the last issue of food safety in developed countries, so since 1987 the HACCP concept has developed, widely discussed and discussed by observers, actors or practitioners of quality control and food safety as well as by bureaucrats and industrialists and food scientists. In fact, because of the high level of safety assurance in each food industry that implements it, this system is widely referred to and adopted as the standard for the food safety process internationally. Therefore, various food safety management has been developed to guarantee the quality and safety of food from production to consumer. One of them is Hazard Analysis Critical Control Point (HACCP).

The researcher conducted a preliminary study which found that one of the CIs at the Nutrition Installation, Kendari City Regional General Hospital, did not implement HACCP at the time of processing food to be served to inpatients. In addition, it is known that the Kendari City Regional General Hospital is one of the largest hospitals in Kendari City. Therefore, the researchers were interested in designing the HACCP at the hospital to ensure the safety of unsafe food which causes a disease called foodborne illness, which is a symptom of a disease that arises from consuming foods containing pathogenic substances / compounds, as well as in minimizing the risk of the danger of foodstuffs being contaminated by substances that can endanger health, a good and standardized food processing sanitation system is needed that can minimize food contamination hazards and ensure food quality.

The Nutrition Installation, Kendari City Regional General Hospital, has a menu cycle of 10 days with four dishes made from fish which is a group or source of animal foods that have a high risk of danger if the handling method is not correct. One of the fish dishes is Pallumara fish soup, which is a dinner menu dish in menu cycle III.

\section{METHODS}

\section{Study Design}

This type of research was a qualitative research with an analytical descriptive approach through interviews to obtain detailed information about the design observations of the HACCP system on an animal dish in the Nutrition Installation of the Kendari City Regional General Hospital.

\section{Setting and Participants}

This research was conducted on 15-17 July 2019 at the Kendari City Regional General Hospital, Indonesia. Palumara fish soup was used as a sample which was observed three times in the third menu cycle. In addition, CI in the nutrition installations and food handlers are directly related to food delivery activities at the Kendari City Regional General Hospital as respondents in this study.

\section{Instrument}

The data included product description, determination of critical control points, arranging process flow, specification of critical limits, determining and implementing the monitoring system, and corrective actions. So, the instruments used were the GMP assessment check list, a work sheet for determining product description, a sheet for making a production process flow chart, a work sheet for hazard analysis and evaluation, a work sheet for determining CCP, a sheet working paper for control and monitoring of the HACCP system.

In addition, all documents originating from the general description of the Nutrition Installation at the Kendari City Regional General Hospital related to the food safety system in food management in the Nutrition Installation were also used as secondary data in this study. The aim was to strengthen findings and complement the information that has been collected through observations and interviews with leaders, employees, and food handlers of the Nutrition Installation of the Kendari City Regional General Hospital.

Data Analysis

After intervention, data were analyzed and processed by classifying the data / information 
that had been systematically compiled beforehand in order to compare the information obtained between the informants and also with the literature using a qualitative approach, then described as information that describes the results that have been obtained.

\section{Ethical Consideration}

This study has been approved by Poltekkes Kemenkes Kendari, Southeast Sulawesi, Indonesia. All participants have received appropriate informed consents.

\section{RESULTS}

The HACCP drafting team in the nutrition installation at the Kendari City Regional General Hospital can be seen in the Table 1, and product descriptions in the Nutrition Installation at Kendari City Hospital can be seen in the Table 2.

Table 1 HACCP Team

\begin{tabular}{llll}
\hline Job Position & Name & Degree & Expertise \\
\hline $\begin{array}{l}\text { Leader of the Food } \\
\text { team }\end{array}$ & Safety & S2 & Food Service HACCP \\
HACCP Leader & Sudarwati, A.MG & DIII & Food Service HACCP \\
$\begin{array}{l}\text { Document control } \\
\text { Member }\end{array}$ & Citra Silawati, AMG & DIII & Food Service HACCP \\
& 1. Heti Siswanto, S.Gz & DIV & \\
2. Sri Dwi H.R., SKM & S1 & Food Service HACCP \\
& 3. Rismawati, A.AMG & DIII & \\
4. Triyana Anastasia, A.MG & DIII & \\
\hline
\end{tabular}

Table 2 Product Descriptions

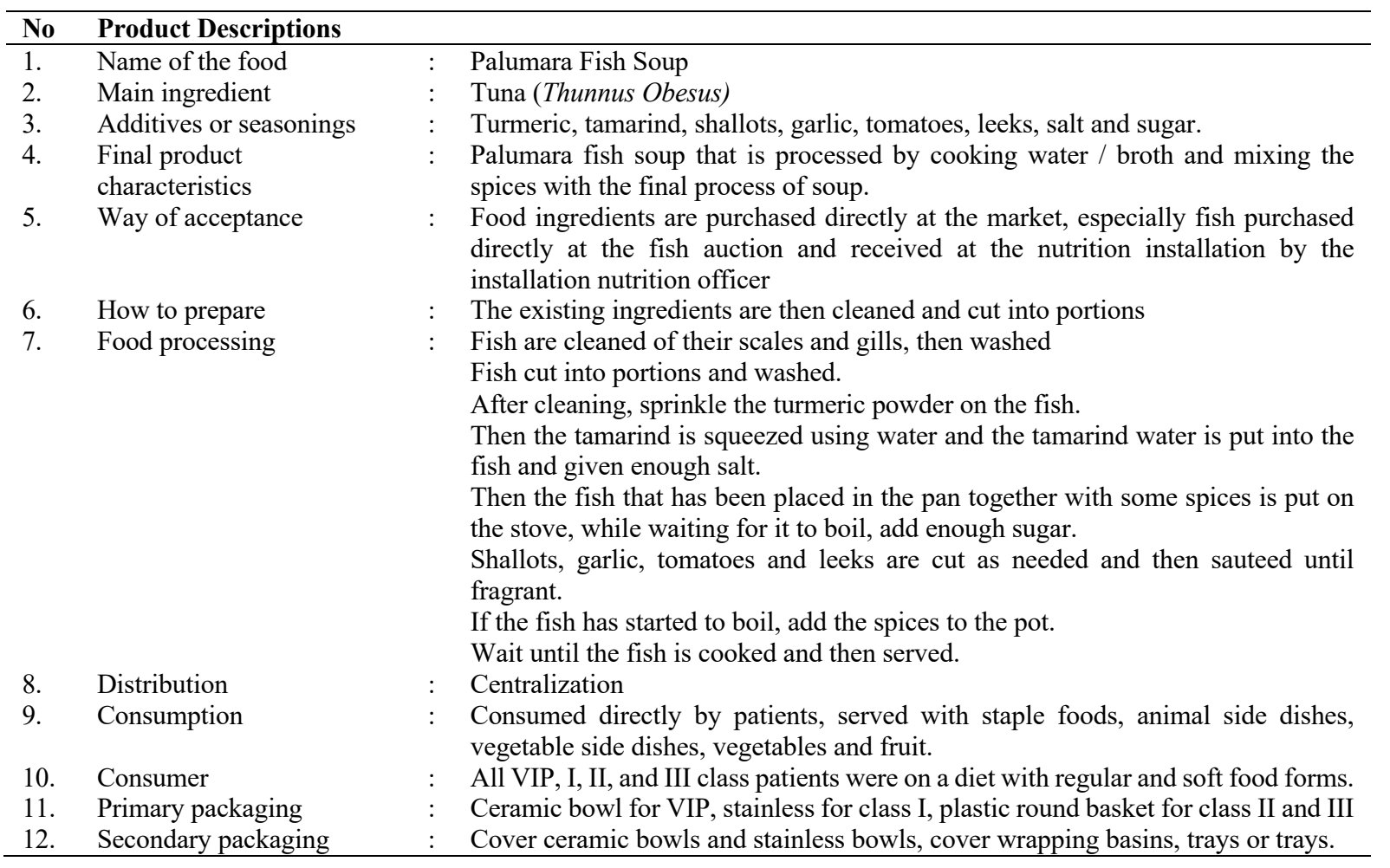

\section{Identification How to Use}

The identification of the Palumara fish soup dish in the nutrition installation of the Kendari City Regional general Hospital were for all VIP, I, II and III class patients who received a diet with regular and soft food forms. As well as the product is directly consumed as an animal side dish. 
Flowchart of Making Palumara Fish Soup The process of making Palumara fish soup at the Kendari City Regional General Hospital begins with the purchase of raw materials, seasonings such as mustache fish, shallots, garlic, turmeric powder, green onions, tomatoes, tamarind, salt, sugar and cooking oil. Raw materials received are still in good condition and in accordance with specifications. Before cooking, all the main ingredients and spices are washed first. Then clean the tools that will be used, after everything is ready, the ingredients can be processed according to a predetermined recipe.

\section{Hazard Analysis and Risk Categories}

From the results of the hazard analysis and risk categories that have been carried out, it is stated that the raw materials and additional materials are in the nutrition installation of the Kendari City regional General Hospital, Tuna fish has contamination with microbiological hazards, such as insects / flies, so handling it by closing the raw material storage container with plastic / wrapping, there is physical hazard contamination with sand and mucus before processing. When receiving raw materials, the handling stage is done by washing clean with running water for one minute. Whereas in tomatoes there is physical hazard contamination originating from sand and dust as for handling with, washing with running water for one-minute, chemical hazards such as residual spraying pesticides and biological hazards originating from flies and caterpillars on tomatoes, so handle it by not storing it in a damp place and open.

In shallots, garlic and leeks, there is a possibility of contamination by physical hazards from onion skins and biological hazards from caterpillars and fungi. In tamarind, there may be physical hazard contamination from impurities such as sand, dust, chemical hazards from pesticides left by spraying and biological hazards from fungi. In powdered turmeric, there may be physical hazard contamination from damaged packaging and chemical hazards that come from the expiration period (changes in aroma, color and taste) as well as biological hazards from fungi. In granulated sugar there is a possibility of physical hazard contamination from dung (small wood) and biological hazards from ants, molds and yeasts. The contaminants identified in this raw material are chemical contaminants, namely the presence of heavy metals and physical contaminants such as threads, ants, filth (hair, pieces of insect body parts).

\section{Risk Analysis/Hazard}

The risk analysis/hazards for Palumara fish soup products presented at the Table 3 and 4 .

Table 3 Hazard Groups

\begin{tabular}{llllllllll}
\hline \multirow{2}{*}{ No. } & \multirow{2}{*}{ Ingredients } & \multicolumn{9}{c}{ Hazard Groups } & \multirow{2}{*}{ Risk Category } \\
\cline { 2 - 6 } & A & B & C & D & E & F & \\
\hline 1. & Tuna (Thunnus Obesus) & - & + & - & + & + & + & IV \\
2. & Tomato & - & + & - & - & - & - & I \\
3. & Onion and garlic & - & + & - & - & - & - & I \\
4. & Tamarind & - & + & - & - & - & - & I \\
5. & Leek & - & + & - & - & - & - & I \\
6. & Turmeric Powder & - & + & - & - & - & - & I \\
7. & Sugar & - & + & - & - & - & - & I \\
8. & Salt & - & + & - & - & - & - & I \\
9. & Cooking oil & - & + & + & - & - & - & II \\
10. & Water & + & + & - & + & + & + & V \\
\hline
\end{tabular}

Table 4 Risk Groups

\begin{tabular}{ll}
\hline 0 & Does not contain hazards A to F \\
I & Contains 1 hazard B to F \\
II & Contains 2 hazards B to F \\
III & Contains 3 hazards B to F \\
IV & Contains 4 hazards B to F \\
V & Contains 5 hazards B to F \\
VI & Highest risk category (all foods containing hazard A, both with / without hazard B to F) \\
\hline
\end{tabular}


Determine Critical Control Points (CCP Decision Tree) on Food and Process Ingredients
Food material

The CCP distribution tree for the food ingredients of the Palumara Fish Soup product that is served at the nutrition installation of the Kendari City Regional General Hospital is shown in the Table 5.

Table 5 Determination of Critical Control Points for Foodstuffs

\begin{tabular}{|c|c|c|c|c|}
\hline \multirow[t]{2}{*}{ No } & \multirow[t]{2}{*}{ Ingredients } & $\begin{array}{l}\text { P.1. } \\
\text { Is it possible that the raw material } \\
\text { contains a hazard at a dangerous level? }\end{array}$ & $\begin{array}{l}\text { P.2. } \\
\text { Does processing (including consumer } \\
\text { use) eliminate or reduce the hazard } \\
\text { to a safe level? }\end{array}$ & \multirow[t]{2}{*}{ Decision } \\
\hline & & $\begin{array}{l}\text { Yes: continued P.2. } \\
\text { No: not CCP }\end{array}$ & $\begin{array}{l}\text { Yes; not CCP } \\
\text { No: } \text { CCP }\end{array}$ & \\
\hline 1. & $\begin{array}{l}\text { Mustache } \\
\text { Brother } \\
\text { Fish }\end{array}$ & Yes & No & CCP \\
\hline 2. & Tomato & Yes & Yes & No CCP \\
\hline 3. & $\begin{array}{l}\text { Onion } \\
\text { and } \\
\text { Garlic }\end{array}$ & Yes & Yes & No CCP \\
\hline 7. & Sugar & Yes & Yes & No CCP \\
\hline 8. & Salt & Yes & Yes & No CCP \\
\hline 9. & $\begin{array}{l}\text { Cooking } \\
\text { oil }\end{array}$ & Yes & Yes & No CCP \\
\hline 10. & Water & Yes & Yes & No CCP \\
\hline
\end{tabular}

Process

The CCP mission tree for the process of the Palumara fish soup product presented at the nutrition installation at the Kendari City Hospital is shown in the Table 6.

Table 6 Determination of Critical Control Points in the Processing Process

\begin{tabular}{|c|c|c|c|c|c|}
\hline No. & Process & $\begin{array}{l}\text { P.1. Is this step } \\
\text { specifically to eliminate / } \\
\text { reduce hazards to a safe } \\
\text { limit? } \\
\text { Yes: CCP } \\
\text { No: continued P.2. }\end{array}$ & $\begin{array}{l}\text { P.2. Can hazard } \\
\text { contamination exceed } \\
\text { limits? } \\
\text { Yes: continued P.3 } \\
\text { No: not CCP }\end{array}$ & $\begin{array}{l}\text { P.3. Whether the next } \\
\text { process can eliminate / } \\
\text { reduce the hazard to a } \\
\text { safe limit? } \\
\text { Yes: not CCP } \\
\text { No: CCP }\end{array}$ & Decision \\
\hline \multicolumn{6}{|c|}{ Sweet and sour fried fish processing } \\
\hline \multirow[t]{8}{*}{1.} & Mustache Brother Fish & & & & \\
\hline & Reception & Yes & - & - & $\mathrm{CCP}$ \\
\hline & Wash cleaning & Yes & - & - & $\mathrm{CCP}$ \\
\hline & Storage & No & Yes & Yes & Not CCP \\
\hline & Soaking in water & No & Yes & Yes & Not CCP \\
\hline & Cutting & No & Yes & Yes & Not CCP \\
\hline & Washing & Yes & - & - & Not CCP \\
\hline & Mixing & No & Yes & Yes & Not CCP \\
\hline 2. & Tamarind & & & & \\
\hline a. & Reception & Yes & - & - & CCP \\
\hline b. & Storage & No & Yes & Yes & Not CCP \\
\hline c. & Washing & No & Yes & Yes & Not CCP \\
\hline d. & Mixing & No & Yes & Yes & Not CCP \\
\hline
\end{tabular}


Table 6 (Cont.)

\begin{tabular}{|c|c|c|c|c|c|}
\hline \multirow[t]{4}{*}{3.} & Sugar, salt, turmeric & & & & \\
\hline & Reception & Yes & - & - & ССР \\
\hline & Storage & No & Yes & Yes & Not CCP \\
\hline & Mixing & No & Yes & Yes & Not CCP \\
\hline \multirow[t]{5}{*}{4.} & Tomato & & & & \\
\hline & Reception & Yes & - & - & CCP \\
\hline & Storage & No & Yes & Yes & Not CCP \\
\hline & Washing & Yes & - & - & CCP \\
\hline & Cutting & No & Yes & Yes & Not CCP \\
\hline \multirow[t]{6}{*}{5.} & Onion and garlic & & & & \\
\hline & Reception & Yes & - & - & $\mathrm{CCP}$ \\
\hline & Storage & No & Yes & Yes & Not CCP \\
\hline & Stripping & Yes & - & - & CCP \\
\hline & Washing & Yes & - & - & CCP \\
\hline & Cutting & No & Yes & Yes & Not CCP \\
\hline \multirow[t]{4}{*}{6.} & Cooking oil & & & & \\
\hline & Reception & Yes & - & - & CCP \\
\hline & Storage & No & Yes & Yes & Not CCP \\
\hline & Stir frying & No & No & - & Not CCP \\
\hline \multirow[t]{3}{*}{7.} & Sugar, Salt & & & & \\
\hline & Reception & Yes & - & - & СCP \\
\hline & Storage & No & Yes & Yes & Not CCP \\
\hline \multirow[t]{7}{*}{8.} & Leek & & & & \\
\hline & Reception & Yes & - & - & CCP \\
\hline & Storage & No & Yes & Yes & Not CCP \\
\hline & Washing & Yes & - & - & CCP \\
\hline & Water & & & & \\
\hline & Storage & No & Yes & Yes & Not CCP \\
\hline & Mixing & No & Yes & Yes & Not CCP \\
\hline 10. & Stir frying & Yes & - & - & CCP \\
\hline 11. & Boiling & Yes & - & - & CCP \\
\hline 11. & Mixing & No & Yes & Yes & Not CCP \\
\hline 12. & Frying & No & Yes & No & $\mathrm{CCP}$ \\
\hline 13. & $\begin{array}{l}\text { Distribution / } \\
\text { presentation }\end{array}$ & No & No & - & $\mathrm{CCP}$ \\
\hline
\end{tabular}

Specification of critical limits, determination, implementation of monitoring systems, and corrective actions

Table 7 HACCP Application

\begin{tabular}{|c|c|c|c|c|c|c|c|}
\hline $\mathrm{CCP}$ & Control & $\begin{array}{l}\text { CCP } \\
\text { Parameters }\end{array}$ & $\begin{array}{l}\text { Critical } \\
\text { Limits } \\
\end{array}$ & Monitoring & $\begin{array}{l}\text { Corrective } \\
\text { Action } \\
\end{array}$ & $\begin{array}{l}\text { Notes/ } \\
\text { Documentation }\end{array}$ & Verification \\
\hline $\begin{array}{l}\text { CCP } 1 . \\
\text { Foodstuff } \\
\text { acceptance }\end{array}$ & $\begin{array}{l}\text { Establish } \\
\text { material } \\
\text { specification } \\
\text { standards in } \\
\text { the receiving } \\
\text { process }\end{array}$ & $\begin{array}{l}\text { There are } \\
\text { insects / flies } \\
\text { in the raw } \\
\text { material }\end{array}$ & $0 \%$ insects & $\begin{array}{l}\text { Check the } \\
\text { food } \\
\text { ingredients } \\
\text { received } \\
\text { according to } \\
\text { specifications }\end{array}$ & $\begin{array}{l}\text { Does not } \\
\text { accept food } \\
\text { ingredients } \\
\text { that are not } \\
\text { suitable / not } \\
\text { according to } \\
\text { specifications }\end{array}$ & $\begin{array}{l}\text { Check the } \\
\text { conformity of } \\
\text { specifications } \\
\text { with raw } \\
\text { materials }\end{array}$ & $\begin{array}{l}\text { Check back } \\
\text { after } \\
\text { acceptance }\end{array}$ \\
\hline $\begin{array}{l}\text { CCP } 2 . \\
\text { Washing food } \\
\text { ingredients }\end{array}$ & $\begin{array}{l}\text { Checking } \\
\text { according to } \\
\text { the } \\
\text { appropriate } \\
\text { specification } \\
\text { s and } \\
\text { standards in } \\
\text { the washing } \\
\text { process } \\
\text { regarding the } \\
\text { use of tools } \\
\text { and PPE }\end{array}$ & $\begin{array}{l}\text { The } \\
\text { presence of } \\
\text { dirt on the } \\
\text { tools used } \\
\text { and food } \\
\text { ingredients, } \\
\text { Escherichia } \\
\text { colli }\end{array}$ & $\begin{array}{l}\text { There are no } \\
\text { foreign } \\
\text { objects or } \\
\text { inedible } \\
\text { parts and no } \\
\text { contaminatio } \\
n \text { from tools } \\
\text { and workers. } \\
0 \% \\
\text { Escherichia } \\
\text { colli content }\end{array}$ & $\begin{array}{l}\text { Check the } \\
\text { specifications } \\
\text { and ensure } \\
\text { that the } \\
\text { ingredients } \\
\text { that are } \\
\text { washed are } \\
\text { clean and } \\
\text { safe }\end{array}$ & $\begin{array}{l}\text { Food } \\
\text { specifications } \\
\text { and standard } \\
\text { operating } \\
\text { procedures } \\
\text { must be clear }\end{array}$ & $\begin{array}{l}\text { Check the } \\
\text { conformity of } \\
\text { foodstuff } \\
\text { specifications } \\
\text { and conformity } \\
\text { to standard } \\
\text { operating } \\
\text { procedures }\end{array}$ & $\begin{array}{l}\text { Re-checking } \\
\text { the appropriate } \\
\text { food } \\
\text { ingredients, as } \\
\text { well as the } \\
\text { conformity of } \\
\text { standard } \\
\text { operating } \\
\text { procedures } \\
\text { with their } \\
\text { application }\end{array}$ \\
\hline
\end{tabular}




\begin{tabular}{|c|c|c|c|c|c|c|c|}
\hline $\begin{array}{l}\text { CCP } 3 . \\
\text { sauteing the } \\
\text { spices }\end{array}$ & $\begin{array}{l}\text { Checking } \\
\text { according to } \\
\text { the } \\
\text { specifications } \\
\text { and standards } \\
\text { in accordance } \\
\text { with the stir } \\
\text { fry process }\end{array}$ & $\begin{array}{l}\text { The level of } \\
\text { doneness of } \\
\text { the } \\
\text { seasonings }\end{array}$ & $\begin{array}{l}\text { Cooked } \\
\text { food } \\
\text { ingredients } \\
\text { at a } \\
\text { temperature } \\
\text { of Saute: } \\
80-100^{\circ} \mathrm{C}\end{array}$ & $\begin{array}{l}\text { Check the } \\
\text { physical level } \\
\text { of maturity, } \\
\text { taste, and } \\
\text { processing } \\
\text { temperature }\end{array}$ & $\begin{array}{l}\text { Perform } \\
\text { reprocessing }\end{array}$ & $\begin{array}{l}\text { Check the } \\
\text { level of } \\
\text { maturity and } \\
\text { cooking } \\
\text { temperature }\end{array}$ & $\begin{array}{l}\text { Check back after } \\
\text { processing }\end{array}$ \\
\hline $\begin{array}{l}\text { CCP } 4 . \\
\text { Peeling } \\
\text { onions }\end{array}$ & $\begin{array}{l}\text { Check } \\
\text { according to } \\
\text { specifications } \\
\text { and standards } \\
\text { in accordance } \\
\text { with the } \\
\text { stripping } \\
\text { process } \\
\text { regarding the } \\
\text { use of tools } \\
\text { and PPE }\end{array}$ & $\begin{array}{l}\text { The } \\
\text { presence of } \\
\text { dirt on the } \\
\text { tools used } \\
\text { and food } \\
\text { ingredients. }\end{array}$ & $\begin{array}{l}\text { There are } \\
\text { no foreign } \\
\text { objects or } \\
\text { inedible } \\
\text { parts and no } \\
\text { contaminati } \\
\text { on from } \\
\text { tools and } \\
\text { workers. }\end{array}$ & $\begin{array}{l}\text { Check the } \\
\text { specifications } \\
\text { and ensure } \\
\text { that the peeled } \\
\text { food } \\
\text { ingredients } \\
\text { are clean and } \\
\text { safe }\end{array}$ & $\begin{array}{l}\text { Food } \\
\text { specification } \\
\mathrm{s} \text { and } \\
\text { standard } \\
\text { operating } \\
\text { procedures } \\
\text { must be clear }\end{array}$ & $\begin{array}{l}\text { Check the } \\
\text { conformity } \\
\text { of foodstuff } \\
\text { specification } \\
\text { s and } \\
\text { conformity } \\
\text { to standard } \\
\text { operating } \\
\text { procedures }\end{array}$ & $\begin{array}{l}\text { Re-checking food } \\
\text { ingredients that are } \\
\text { appropriate, as well } \\
\text { as conformity to } \\
\text { standard operating } \\
\text { procedures with its } \\
\text { application }\end{array}$ \\
\hline $\begin{array}{l}\text { CCP } 5 . \\
\text { Boiling fish }\end{array}$ & $\begin{array}{l}\text { Check } \\
\text { according to } \\
\text { the } \\
\text { specifications } \\
\text { and standards } \\
\text { according to } \\
\text { the cooking } \\
\text { process }\end{array}$ & $\begin{array}{l}\text { The level of } \\
\text { maturity of } \\
\text { the food }\end{array}$ & $\begin{array}{l}\text { Cooked } \\
\text { food } \\
\text { ingredients } \\
\text { at boiling } \\
\text { temperature } \\
: 100^{\circ} \mathrm{C}\end{array}$ & $\begin{array}{l}\text { Check the } \\
\text { physical level } \\
\text { of maturity, } \\
\text { taste, and } \\
\text { processing } \\
\text { temperature }\end{array}$ & $\begin{array}{l}\text { Perform } \\
\text { reprocessing }\end{array}$ & $\begin{array}{l}\text { Check the } \\
\text { level of } \\
\text { maturity and } \\
\text { cooking } \\
\text { temperature }\end{array}$ & $\begin{array}{l}\text { Check back after } \\
\text { processing }\end{array}$ \\
\hline $\begin{array}{l}\text { CCP } 6 . \\
\text { Casting }\end{array}$ & $\begin{array}{l}\text { The existence } \\
\text { of standard } \\
\text { portions and } \\
\text { standard } \\
\text { operating } \\
\text { procedures for } \\
\text { the tools and } \\
\text { containers } \\
\text { used }\end{array}$ & $\begin{array}{l}\text { The } \\
\text { presence of } \\
\text { contaminatio } \\
\mathrm{n} \text { during } \\
\text { pouring } \\
\text { from tools, } \\
\text { containers } \\
\text { and workers, } \\
\text { Escherichia } \\
\text { colli }\end{array}$ & $\begin{array}{l}0 \% \\
\text { Escherichia } \\
\text { colli content }\end{array}$ & $\begin{array}{l}\text { Re-checking } \\
\text { the proper } \\
\text { food, } \\
\text { conformity } \\
\text { with standard } \\
\text { operating } \\
\text { procedures } \\
\text { related to } \\
\text { hygiene and } \\
\text { sanitation for } \\
\text { equipment } \\
\text { and workers }\end{array}$ & $\begin{array}{l}\text { Replace } \\
\text { unsuitable } \\
\text { food, replace } \\
\text { tools and } \\
\text { containers } \\
\text { that are not } \\
\text { suitable and } \\
\text { pay attention } \\
\text { to standard } \\
\text { operating } \\
\text { procedures } \\
\text { related to } \\
\text { improving } \\
\text { worker } \\
\text { hygiene }\end{array}$ & $\begin{array}{l}\text { Check the } \\
\text { amount of } \\
\text { food in the } \\
\text { food } \\
\text { container and } \\
\text { the } \\
\text { conformity } \\
\text { of standard } \\
\text { operating } \\
\text { procedures } \\
\text { with its } \\
\text { application }\end{array}$ & $\begin{array}{l}\text { Recheck the food } \\
\text { after frying }\end{array}$ \\
\hline $\begin{array}{l}\text { CCP } 7 . \\
\text { Distribution }\end{array}$ & $\begin{array}{l}\text { Containers and } \\
\text { trolly used are } \\
\text { free of } \\
\text { contamination, } \\
\text { limited time } \\
\text { used, use of } \\
\text { PPE }\end{array}$ & $\begin{array}{l}\text { There is } \\
\text { contaminatio } \\
\mathrm{n} \text { between } \\
\text { food and } \\
\text { food } \\
\text { containers or } \\
\text { food carts } \\
\text { and } \\
\text { contaminatio } \\
\mathrm{n} \text { of } \\
\text { workers, } \\
\text { Escherichia } \\
\text { colli }\end{array}$ & $\begin{array}{l}0 \% \\
\text { Escherichia } \\
\text { colli content }\end{array}$ & $\begin{array}{l}\text { Checking the } \\
\text { container and } \\
\text { trolly used, } \\
\text { checking the } \\
\text { distribution } \\
\text { time and } \\
\text { distance }\end{array}$ & $\begin{array}{l}\text { Changing } \\
\text { food } \\
\text { containers } \\
\text { that are not } \\
\text { suitable, } \\
\text { adjusting the } \\
\text { distribution } \\
\text { time }\end{array}$ & $\begin{array}{l}\text { Check the } \\
\text { procedure for } \\
\text { washing } \\
\text { containers, } \\
\text { using PPE }\end{array}$ & $\begin{array}{l}\text { Re-check the } \\
\text { cleanliness of the } \\
\text { trolly and food } \\
\text { containers and the } \\
\text { use of PPE }\end{array}$ \\
\hline
\end{tabular}

\section{DISCUSSION}

\section{HACCP Team}

In the research conducted at the Kendari City Regional General Hospital, there was no HACCP team, where the HACCP team sought from various fields of engineering, production, sanitation, quality assurance, and food microbiology. The team also includes staff involved in the production process, so in the preparation of the HACCP team must meet the requirements and be competent in a predetermined field. Then the HACCP team is formed through the nutrition installation staff and the person in charge for the installation guarantee success in designing the HACCP. The HACCP team is composed of individuals who have specific knowledge and expertise in accordance 
with products and processes. The HACCP team in the Kendari City Regional General Hospital consists of a leader and several team members.

\section{Product Descriptions}

The product description is a complete picture of the product which is a complete picture of the product including information on composition, physical structure, packaging, storage conditions, and distribution methods (Peraturan Kepala Badan Standarisasi, 1994).

Palumara fish soup with the main ingredient of mustache brother fish which is processed in a soup with added turmeric and tamarind and mixed with sautéed spices, shallots, garlic, tomatoes, and leeks. The characteristics of the final product are gravy and consumed directly by the patient as an animal side dish for all classes including VIP, I, II, and III. Product description Palumara fish soup which is presented on menu III for the evening at the nutrition installation at Kendari City Hospital. Palumara fish soup with the main ingredient of big eye tuna which is processed in a soup with added turmeric and tamarind and mixed with sauteed onions, garlic, tomatoes and leeks. The characteristics of the final product are gravy and consumed directly by the patient as an animal side dish for all classes including VIP, I, II, and III.

The selected fish is adjusted to the fish to be processed, as well as the availability of existing fish, fish receipts are usually bought directly on the market or fish auction by one of the nutrition installation officers in the reception section, the purchased fish is adjusted to the specifications and forms of food ingredients that are already available. The fish that have been purchased are stored in the freezer storage at a temperature of $0^{\circ} \mathrm{C}-5^{\circ} \mathrm{C}$. This temperature is valid for $1-3$ days of storage.

In the preparation stage, the main ingredients are usually taken with existing ingredients that have been stored in the freezer. The main material is then cleaned, the fins are removed and washed thoroughly and then cut as needed. The packaging for the Palumara fish soup dish is ceramic bowl for VIP, Steinlees for class I, plastic round basket for class II and III. As well as for packaging covers for ceramic and steinless cups, cover plastic containers, trays and trays. The Palumara fish soup dish is consumed for all patients who are on a diet with regular and soft food forms.

In the distribution process, namely centralization which is delivered directly to the patient from the nutrition installation to the patient's room.

\section{Identification How to Use}

It is very important to identify the intended use of the product in advance, because it will be related to the level of complexity in determining the types of hazards and critical limits that will be further identified (Mortimore \& Wallace, 2013).

Each product that is controlled through the application of the HACCP system must first be determined for its use plan or in other words, it must be identified first formerly the target consumers. In a risk analysis, the level of danger of a product will be related to its target consumers (Wallace, Sperber, \& Mortimore, 2018).

As for the requirements for identifying how to use, namely, the use plan such as ready to consume and there needs to be further processing or mixing with other foods, then handling by consumers who are likely to be misused, must have a special target and user group.

The results of the identification of the final destination of the Palumara fish soup dish in the nutrition installation of the Kendari City Hospital were for all VIP, I, II and III class patients who received a diet with regular and soft food forms. As well as the product is directly consumed as an animal side dish.

\section{Flowchart of Making Palumara Fish Soup}

Creating a flow chart need not be complicated by describing the process from receiving to sending. To find all food safety hazards in the manufacturing process, it is necessary to know the exact steps that the product goes through. The purpose of a flow chart is to provide a clear, simple description of all the steps involved in processing. The steps for receiving and storing raw materials must be included (Mortimore \& Wallace, 2013). The flow chart or flow chart that 
is made must contain all stages in the production operation (Wallace et al., 2018).

The process of compiling a flow chart is carried out to determine the process of making Palumara fish soup from start to finish. The flow chart that has been made is not said to be the same as the actual process, but it still requires evaluation and certainty and certainty of direct observation.

\section{Hazard Analysis and Risk Categories}

Hazard analysis is a systematic evaluation of specific foods and raw materials or ingredients to determine risk. Food safety risks that must be examined include: chemical contamination safety aspects, physical contamination safety aspects, and biological safety aspects including microbiology (Irfan M, 2016).

Chemical contamination in sugar can be in the form of sulfur dioxide. With salt there may be physical hazards from dirt, sand, and gravel, and chemical hazards from evaporation due to storage temperatures. In cooking oil, there may be chemical hazards that come from repeated use of the oil. In water there is a possibility of contamination, physical hazards come from foreign objects / dirt and biological hazards from Eschericia coli with clean and safe water handling, while chemical hazards come from metal contamination so that handling ensures that water boils up to $100^{\circ} \mathrm{C}$ (Surahman \& Ekafitri, 2014).

\section{Risk Analysis/Hazard}

The hazard analysis is carried out through the hazard group table and the risk group table. Qualitative hazard potential analysis is carried out by combining probability and acuity / severity. The hazards with the potential to have a high risk must be followed up with corrective actions, and while the hazards with medium potential are carried out with precautionary measures. So that the hazard analysis can determine how dangerous the material to be used is.

Hazard identification is a specific evaluation of food products and raw materials, ingenious ingredients and additives to determine the risk of biological, chemical and physical hazards.
Hazard is identified as a biological, chemical or physical agent or condition in food that has the potential to cause adverse health effects (Mortimore \& Wallace, 2013). The food products produced by the nutrition unit are intended for high-risk populations, namely the sick. Identification of product use plans related to risk analysis or the level of danger of a product (Sudarmaji \& Zulfana, 2008).

At this stage the risk categories are assigned to foodstuffs based on hazard groups which are then categorized into categories 0 - IV. The flying fish material is included in risk category IV, which contains 4 dangers B to $F$. In the ingredients of tomatoes, onions, garlic, tomatoes, tamarind, turmeric powder, leeks, sugar, salt are included in risk category I, which contains 1 danger. $\mathrm{B}$ to F. Cooking oil is categorized as risk II, which contains 2 hazards B to F. Whereas water is classified as risk category $\mathrm{V}$ contains 5 hazards $\mathrm{B}$ to F.

Determine Critical Control Points (CCP
Decision Tree) on Food and Process
Ingredients
From the results of this identification, a so-called Critical Control Point (CCP) will be obtained. CCP can be defined as a point, or stage or procedure in food processing that can be controlled so that hazards can be prevented or reduced to levels that are considered safe.

At this stage, the determination of critical control points is carried out on food and process ingredients (can be seen in tables 6 and 7) based on the results of the analysis using a decision tree. For food ingredients, none of them are included as CCP and some are included as CCP at the process stage.

Critical limits are the maximum or minimum values of identified biological, chemical or physical hazards which must be controlled at a critical point in order to prevent, eliminate or reduce the hazard to a level considered safe. Each CCP will have one or more precautionary measures that must be properly controlled to ensure the prevention, elimination or reduction of harm to an acceptable level (Surahman \& Ekafitri, 2014). 
In food ingredients, all ingredients used to make Palumara fish soup are not CCP because they have passed two stages, namely the first stage the possibility of the raw material containing a hazard at a dangerous level and the second stage whether processing can eliminate or reduce the hazard at a safe level. From the two stages, it was decided that the food ingredient was not CCP other than fish which was CCP due to the possible dangers of using formaldehyde that cannot be eliminated.

In SNI-01-4852-1998, each critical control point (CCP) that has been defined must have a critical limit specification to define the boundary between acceptable and unacceptable conditions and that critical limit must be met to ensure that the CCP can be properly controlled. Frequent criteria used in determining the critical limit usually includes temperature, time, humidity level, $\mathrm{pH}$, aw and chlorine parameters, visual parameters, and texture (Mortimore \& Wallace, 2013).

The process which is a CCP must be carried out properly according to the SOP, in order to eliminate the hazards that occur. Failure to perform certain processes can cause harm to the production system. The process which is a $\mathrm{CP}$ also still requires control to prevent potential hazards (Rachmadia, Handayani, \& Adi, 2018).

Cooking of foodstuffs is a CCP because this process is designed to destroy any potential hazard to an acceptable level. The most effective and easiest way to kill microorganisms is by heating because above the maximum temperature that supports their growth, microorganisms will die. The time or length of heating to make food safe also depends on how many organisms are initially present (Sudarmaji \& Zulfana, 2008). Whereas in the preparation stage the HACCP decision is given because at this stage it is specifically for eliminates / reduces hazards to a safe limit. At the processing stage the CCP decision is given because at this stage it is specifically for eliminate / reduce hazards to a safe limit. At the boiling stage, the CCP decision was given because this stage was specifically to eliminate / reduce hazards to a safe limit. At the correct stage, the CCP decision is given because at this stage it does not exist further process to eliminate / reduce the hazard to a safe limit. At the storage stage before distribution the CCP decision is given because at this stage there is no further process eliminates / reduces hazards to a safe limit.

At the distribution / presentation stage the $\mathrm{CCP}$ decision is given because at this stage there is no further process to eliminate / reduce hazards to a safe limit.

Specification of Critical Limits, Determination, Implementation of Monitoring Systems, and Corrective Actions

Determination of critical limits for each CCP using critical parameters, namely temperature, time, the amount of E. Coli in processed food, organoleptic aspects (color, smell, taste, texture) for ready-to-eat food, number of wok or certain products in food formulations, number of calories as well as the content of certain substances in food (Fauziah \& Balaka, 2018)

Corrective action is taken if there is a deviation from the critical limit of a CCP. Corrective action taken in the event of a deviation depends on the level of risk of the food product. For high-risk food products, for example, corrective action may interrupt the product process before the deviation is corrected / corrected, or the product is detained / not marketed and its safety tested. Corrective actions that can be taken besides stopping the production process include eliminating products and product rework, as well as preventive measures such as verifying any changes any changes that have been implemented in the process and ensure it remains effective (Rahmatunna Rusli \& Nurlaela, 2019).

In each material to be processed, it must have a specification limit, the purpose of the specification is to alleviate further work for determining the critical control point (CCP). Based on the results of the research on the critical control point, the critical limit of the dangers that might be found in Palumara fish soup was determined. One of the critical limits specified in the acceptance process is that all materials are suitable for use by observing the standard specifications. In the preparation process, the 
critical limit is that there are no foreign objects or inedible parts. In the processing process, the critical limit specified is cooked food. Cooking food can also be interpreted as the process of heating food and destroying microorganisms that may be found in these food products. The process of destroying these microorganisms is directly related to the time and temperature of food handling. Accuracy in the food cooking process is very important for safe and healthy food preparation so that cooked food must be at a safe temperature so that bacteria and microorganisms do not live and reproduce (Khotimah, 2015).

In the process of casting, the critical limit determined is that there is no contamination. In the storage process before the distribution of the critical limit, there is no contamination. In every food handling must pay attention to temperature and time, because the temperature and time are wrong is a high risk of food in the danger zone (Khotimah, 2015). Meanwhile, for the distribution / presentation stage, the critical limit determined is that there is no contamination.

Establish and Implement A Monitoring System in the Palumara Fish Soup Processing Process

Monitoring aims to determine any deviations from the criteria that have been made, the results of monitoring should be obtained immediately so that if necessary the process can be corrected quickly (Sudarmaji \& Zulfana, 2008).

The critical limit that has been determined on a CCP must be monitored for its existence. This is to determine whether the CCP processing or handling procedures are under control. Monitoring method can be done by observation (sensory, visual) and measurement (chemical, physical). What will be monitored is starting from the stage of receiving foodstuffs from shopping officers to the distribution stage (Irfan M, 2016).

From the results of observations on the process of receiving the monitoring system carried out is checking the received food ingredients according to specifications. In the preparation stage of the monitoring system, which will be carried out is to check specifications and ensure that the food prepared is clean and safe. In the monitoring system processing process that will be carried out is checking the level of maturity both physically, taste, nor the processing temperature. In the process of processing the monitoring system that will be carried out is re-checking the proper food, hygiene and sanitation of tools and workers.

In the storage stage prior to distribution, the monitoring system that will be carried out is replacing food containers that are not suitable and adjusting processing time with distribution time. While at the stage distribution / presentation of the monitoring system that will be carried out is replacing food containers that are not suitable and adjusting the distribution time. Based on minister of health regulations Number 1096 / MENKES / PER / VI / 2011, the distance and travel time from the food processing place to the serving place as well as the obstacles that may occur during transportation will affect the serving conditions (Khotimah, 2015).

\section{Take Corrective Action on Palumara Fish Soup}

Sometimes a certain critical stage of the process is not under adequate control so that the resulting product cannot be declared safe. To anticipate the unwanted work, a corrective action procedure must be made. Corrective action is an action that must be taken or decided based on the results of monitoring of the $\mathrm{CCP}$, which indicates that the CCP is out of control (Irfan M, 2016).

The results of observations made in the process of receiving corrective action that will be taken are not receiving food ingredients that are not suitable / not according to specifications. In the preparation stage, the corrective actions taken are the material specifications and the preparation process which must be clear. At the processing stage, the corrective action that will be taken is reprocessing. At the correcting stage, the corrective action to be taken is to check the hygiene and sanitation of the container and workers. In the storage stage before distribution, the corrective action taken is to check the sanitary hygiene of the container and workers as well as the time before distribution. At the distribution / presentation stage, the corrective action taken is to check the sanitation hygiene of the container 
and workers as well as the time before distribution. Healthy humans alone are a source of microbes such as Streptococcus from feces and Staphylococcus from the skin, nose, mouth and throat. Whenever a worker's hands come into contact with parts of the body that contain pathogenic microbes, the hands will become contaminated and when the hands come into contact with food, contamination occurs immediately. Contamination also occurs through the air from the mouth, breath, and also from clothing.

\section{CONCLUSION}

The nutrition installation at the Kendari City Regional General Hospital has not implemented GMP as a whole, both from manpower, buildings, sanitation facilities and equipment. In addition, the nutrition installation at Kendari City Hospital has not implemented HACCP in the food processing process, from the reception to distribution stage, so there are risks and dangers in Palumara fish soup. Therefore, it is suggested to the Kendari City Regional Hospital hospital to implement the HACCP system to minimize the incidence of hazardous contamination in food and better ensure food quality.

Declaration of Conflicting Interest

The authors would like to declare that they have no conflict of interests in this study.

Acknowledgments

The authors would like to extend their sincere thanks to Harar Health Science College and health facilities, as well as special thanks to all data collectors, supervisors and study participants.

Funding

No funding for this study.
References

Departemen Kesehatan Republik Indonesia. (2006). Pedoman penyelenggaraan dan prosedur rekam medis rumah sakit di Indonesia. Jakarta: Departemen Kesehatan Republik Indonesia

Fauziah, P., \& Balaka, S. (2018). HACCP pada proses pengolahan ikan goreng asam manis di instalasi gizi RSAD Dr. R ISMOYO Kendari. Kendari: Poltekkes Kemenkes Kendari.

Irfan M. (2016). Penerapan (HACCP) pada proses pengolahan ikan goring saos tomat di instalasi gizi Rumah Sakit BLUD Bahteramas. Kendari: Poltekkes Kemenkes Kendari.

Khotimah, M. (2015). Gambaran penerapan food safety pada pengolahan makanan di Instalasi Gizi Rumah Sakit Bhakti Wira Tamtama Semarang. Semarang: Universitas Negeri Semarang.

Mortimore, S., \& Wallace, C. (2013). HACCP: A practical approach. Berlin: Springer Science \& Business Media.

Badan Standarisasi Nasional. (1994). Peraturan Kepala Badan Standarisasi Nasional. Jakarta: Badan Standarisasi Nasional

Rachmadia, N. D., Handayani, N., \& Adi, A. C. (2018). Penerapan sistem Hazard Analisis Critical Control Point (HACCP) pada produk ayam bakar bumbu herb di Divisi Katering Diet PT. Prima Citra Nutrindo Surabaya. Amerta Nutrition, 2(1), 17-28.

Rahmatunna Rusli, P., \& Nurlaela, E. (2019). Rancangan HACCP (Hazard Analysis Critical Control Point) pada hidangan makanan sup ikan pallumara di Instalasi Gizi RSUD Kota Kendari. Kendari: Poltekkes Kemenkes Kendari,

Sudarmaji, S., \& Zulfana, I. (2008). Hazard Analysis and Critical Control Point (HACCP) pada pengelolaan makanan pasien Rawat Inap di Rumah Sakit Islam Lumajang. Jurnal Kesehatan Lingkungan Unair, 4(2), 3922.

Surahman, D. N., \& Ekafitri, R. (2014). Kajian HACCP (Hazard Analysis and Critical Control Point) pengolahan jambu biji di Pilot Plant Sari Buah UPT. B2PTTG-LIPI Subang. Agritech, 34(3), 266-276.

Wallace, C. A., Sperber, W. H., \& Mortimore, S. E. (2018). Food safety for the 21st century: Managing HACCP and food safety throughout the global supply chain. New Jersey: John Wiley \& Sons.

Cite this article as: Yunancy, S., Nurlaela, E., \& Rusli, R. (2020). Hazard analysis critical control point (HACCP) on Palumara fish soup in the nutrition installation of the regional general hospital, Indonesia. Public Health of Indonesia, 6(4), 145-156. https://dx.doi.org/10.36685/phi.v6i4.358 